\title{
ANIMAL NAMES USED AS INSULTS AND DEROGATION IN POLISH AND SPANISH ${ }^{1}$
}

\author{
Pedro J. Chamizo Dominguez \\ Universidad de Málaga \\ Magdalena Zarwislawska \\ Universidad de Varsovia (Polonia)
}

\begin{abstract}
RESUMEN
Este artículo versa sobre los nombres de animales usados metafóricamente para significar diversos aspectos en el dominio de lo bumano (caracteristicas físicas y mentales, partes del cuerpo, fluidos corporales, enfermedades y acciones humanas) y que pueden ser usados como formas de desprecio o insulto. Generalmente los nombres de los animales que se aplican a las personas son ofensivos. De hecho, solo bay unos pocos ejemplos de nombres de animales que no tienen matiz peyorativo. En este artículo se analiza el material léxico de corporal españoles y polacos. Puesto que la clase de los animales es muy extensa y diversa, la hemos dividido en varias subclases. En la primera incluimos los nombres de animales de acuerdo con los siguientes criterios: 1) referidos a características físicas del ser bumano, 2) referidos a los órganos sexuales bumanos y a la sexualidad bumana, 3) referidos a los caracteres bumanos, 4) referidos a grupos bumanos, 5) para significar trabajos y ocupaciones, 6) para nombrar secreciones, enfermedades, heridas e intoxicaciones humanas. En segundo lugar estudiamos los nombres de las partes de los cuerpos de los animales, sus secreciones, conducta y sonidos, así como los nombres de las acciones típicamente animales. El último grupo analizado es el de los derivados (nombres, adjetivos y verbos) de los nombres de los animales aplicados al dominio bumano.
\end{abstract}

Palabras clave: zoosemia, metáfora, desprecio, insulto, peyoración, obscenidad, lexicalización, español, polaco.

1 This research has been supported by The Research Foundation for Foreign Researchers. Vicerrectorado de Investigación. Universidad de Málaga. Ref. 200400100014531. We acknowledge Dr. Keith Allan (Monash University, Australia) and Dr. Stavroula Varella (University of Sussex, UK) their helpful comments, suggestions, and corrections. 


\begin{abstract}
This article deals with animal names which metaphorically signify various aspects of humans (physical and mental features, body parts, secretions, ill-states and actions), and can be used as derogation or insult. Generally animal names which are applied to a person are offensive. There are only few examples of animal names which do not have pejorative evaluation. In the article, lexical material from Polish and Spanish corpora is analyzed. Since the class of animal names is very extensive and diverse, it has been divided into several subclasses. The first one contains animals: 1) referring to physical features of a buman being, 2) referring to the buman pudenda and sexual activity, 3) naming feature of human character, 4) referring to a group of people, 5) signifying jobs and occupations, 6) naming buman secretions, diseases, injuries, intoxications. Then names of animal body parts are described, secretions and animal states, behavior, sounds made by them and also names of actions performed on animals by a man. The last class analyzed in the present article, contains derivatives (nouns, adjectives and verbs) of animal names.
\end{abstract}

Keywords: zoosemy, metaphor, derogation, insult, pejoration, obscenity, lexicalization, Spanish, Polish.

\title{
1. INTRODUCTION
}

The metaphorical transfers from animal domain to human domain can be found in any language and in any culture, as in any kind of language, namely cultured, vulgar, obscene, philosophical or scientific. They can be used for naming or alluding to a person (e.g. bird for «a maiden, a girl [...]. In modern (revived) use: a girl, woman (often used familiarly or disparagingly)» $(O E D)){ }^{2}$ Sitting Bull for the well-known Sioux Chief), a religious symbol or entity (e.g. the dove symbolizes The Holy Ghost, the owl symbolizes Minerva, the fish symbolizes Christ), ${ }^{3}$ an act (e.g. to dog for to have coitus a tergo), a political party (e.g. the donkey for American Republican Party and the elephant for American Democrat Party), a philosophical school (e.g. the Cynics for the philosophical school

2 Continental quotation marks («») will enclose textual quotations as well as the titles of articles in journals or anthologies.

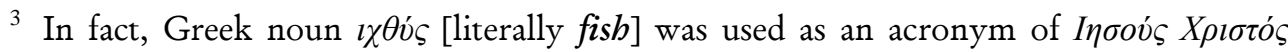
@eov́ Yióৎ [Iēsous Christos Theou Huios Sōtēr] meaning Jesus Christ, Son of God, Saviour. 
founded by Antisthenes), ${ }^{4}$ or symbolizing a city (e.g. the bear is the symbol of three cities at least - Madrid, Berlin and Bern) or a nation (e.g. the cock is the symbol of both France and Portugal; the bull is the symbol of Spain; the eagle is the symbol of Poland and USA. They are also used for praising and derogating, for exalting and insulting, and even for naming in an axiologically neutral way.

Since metaphorical transfers can be found anywhere, they can be regarded as a linguistic universal if they are considered from an empty point of view. But, since the name of a given animal can get different metaphorical meanings in the human domain in different languages, animal metaphors can be divided into general and particular ones. General metaphors are the kind of transfers which are shared in several languages and/or cultures. As a result, these nouns can be translated from one language to another, in both their literal and metaphorical senses, and achieve the same meanings. So, pigs are considered as being the paradigm of dirtiness in almost all European languages and for that reason the noun pig can be metaphorically used in European languages to mean any dirty person and to refer to both moral and physical dirtiness; and its derivative pigsty to mean any dirty or untidy place. By contrast, particular metaphors are those which only work in a given language or culture. So, the Spanish noun canguro literally means kangaroo and metaphorically babysitter, and, since the English name does not get the same metaphorical meaning as its Spanish equivalent, the one can't be translated into the other to achieve the same meaning. By contrast, the English collocation kangaroo court has the metaphorical meaning of «an ad hoc investigation» (Holder, 2003: 219), ${ }^{5}$ and, since this metaphorical meaning does not work in Spanish, its literal translation into Spanish as tribunal canguro would be meaningless. Similarly the various cognates in several European languages of the noun camel literally mean the animal itself, but all of them have different metaphorical meanings in the most various European languages and (almost) none of them coincide (Burgen, 1996:196). Among other meanings, Spanish camello means drug pusher, Catalan camell also means drug pusher, ${ }^{6}$

${ }^{4}$ Although the word cynic [from Greek $\kappa v ́ \omega v$ ] probably doesn't evoke the noun $d o g$ to English speakers except perhaps scholars, it should be stressed that it evokes the animal to any speaker of Greek language even nowadays.

5 Although it can't be found in Holder's book -perhaps because it is not a euphemistic meaning, M. Prado (Prado, 2001: 282) also adds the metaphorical meaning of «expresión que se aplica también a una comedia que es una sátira de la sociedad, al estilo de los sainetes de Carlos Arniches».

${ }^{6}$ Catalan camell also has the metaphorical meaning of «Noi o noia que té les cames llargues» [boy or girl who has long legs] (Alcover \& Moll, 1930). 
Portuguese camelo means benpecked, French chameau means whore and nasty piece of work, German Kamel means stupid or silly, Italian cammello means ugly, and eventually -although it is probably not lexicalized yet- English camel means drug pusher (see below).

On the other hand, from an axiological point of view animal metaphors can be divided into neutral, ameliorative, pejorative, obscene, and polysemous ones:

- NeUTRAL. Spanish boquerón [anchovy] metaphorically means "inhabitant/native of Malaga". Similarly Spanish gato/gata [cat/she-cat] metaphorically mean «hombre nacido en Madrid» and «mujer nacida en Madrid» (DRAE) ["man born in Madrid" and "woman born in Madrid", respectively]. And neither boquerón nor gato/gata has any pejorative or derogatory connotations. ${ }^{8}$ Polish narybek [fry] metaphorically means new, young, team (SJPSz).

- AMELIORATIVE. Although Spanish pata [animal leg] usually has a pejorative meaning when used of a buman leg [pierna, in Spanish], the collocation (de) pata negra [(of/from) black leg] always has an ameliorative connotation and means top-class, top-notch, or prime. Although Polish bestia [beast] usually has derogatory connotations (e.g. Co za bestia z tego ojca, żeby tak bić swoje dziecko [What a beast that father is to beat his own child]), it can be used in an admiring way (e.g. Co za zdolna bestia $z$ ciebie [What a clever beast you are!]).

- Pejorative. Some animal terms are always pejorative/obscene/derogatory. So, Spanish cabrón [literally he-goat, and metaphorically cuckold and bastard] is always used as an insult or in a derogatory way. Polish ropucha [literally toad, and metaphorically ugly, old woman] (KSJP) is always used as an insult or in a derogatory way.

7 Although the meaning of $u g l y$ is not lexicalized for Spanish camello, it can be occasionally found, as in the following joke:

Cuando te veo me acuerdo del desierto [I am reminded of the desert when I see you].

¿Por qué? ¿Por mi delgado y esbelto talle de palmera? [Why? Because of my slim, svelte figure like a palm tree?].

No. Por tu cara de camello [No. Because of your camel face].

8 We would stress that in this case we mean their referential meanings. We disregard affective or register connotations. 
- OBSCENE. Spanish polla [literally young hen, and metaphorically cock/penis] has always an obscene meaning in the Spanish spoken in Spain. ${ }^{9}$ Polish kon [literally horse, and metaphorically cock/penis] in colloquial style can have an obscene meaning.

- POlysemous. Finally some of them get their derogatory meanings depending on the context. So, Spanish lagarta [she-lizard] can mean «mujer taimada» [sly woman, sly minx] and/or "prostituta» [whore, tart] (DRAE). Similarly, Polish fladra [flounder] means 'someone dirty, shabby' and/or 'whore, tart'.

A metaphor can be found in any of these three stages (Chamizo Domínguez, http://www.ensayistas.org/critica/retorica/chamizo/cap3.htm):

- CREATIVE OR NEW. A creative or new metaphor is a given metaphor which is used or proposed by a given speaker in a given context and which is not part of a metaphorical network in a given language. E.g. the noun camel is occasionally used to mean metaphorically «a smuggler of illegal narcotics» (Holder, 2003: 51) and it is not included in the $O E D$ yet, probably because this metaphorical meaning is pretty recent in English. And since Holder's quote deals with Gibraltar Straits («Algeciras is known as 'the marijuana gateway to Europe', being the unloading point from Tangier and the Ceuta enclave for most 'camels'; the jeep and truck drivers of hash loads from the Rif»), we dare to suggest that this meaning is probably a borrowing of the lexicalized, metaphorical meaning of Spanish camello [drug pusher]. Now, if this new meaning is widely used in English in the future, it will become firstly semi-lexicalized, secondly lexicalized, and eventually included in standard dictionaries. ${ }^{10}$

- SEMI-LEXICALIZED. When a given creative or new metaphor is widely used by a group of speakers -and, for such a reason understood, it usually becomes a semi-lexicalized one and is eventually included in standard dictionaries. Terms becoming semi-lexicalized metaphors get

9 Surprisingly, polla metaphorically means lottery in South America.

${ }^{10}$ The usual English and French animal metaphor for 'drug pusher' is mule. Spanish mula also means «contrabandista de drogas en pequeñas cantidades» [drug pusher in small quantities] in some South American countries. But, in Cuba, mula means «hombre homosexual» [homosexual man] (both DRAE), while mula and mulo [she-mule and hemule, respectively] mean stubborn, brute, animal, beast, and/or ass, idiot, in Spain. [Eng.. stubborn as a mule]. 
two meanings at least, their literal and metaphorical meanings. The majority of metaphors belong to this kind. E.g. English cock means both rooster and penis. Classical conceptual, metaphorical networks studied by Lakoff and Johnson [1980] are typically built on semilexicalized metaphors.

- LEXICALIZED. And eventually, when a second order or figurative meaning of a term becomes the norm in a speech community, that meaning tends to be lexicalized and is then regarded as the normal or literal meaning of the term. And this happens to such an extent that speakers completely lose any linguistic awareness that it was once a figurative term. E.g. Cock keeps up its first order (literal) meaning in British English yet and for such a reason it can be used in Britain in order to mean the animal. By contrast, in America, its first order meaning is penis and for such a reason cock became a bawdy, obscene term in American dialect and Americans are obliged to use rooster if they want not be misunderstood or something worse. ${ }^{11}$ Although a large number of stages can be distinguished in the lexicalization process of figurative meanings, and although this process does not follow the same route with every speaker, we can say that the process has ended when the term in question loses the three basic features that had enabled us to classify it as a metaphor. A paradigmatic example of a completely lexicalized metaphor can be the one of the equivalents for English cunt in several European languages, ${ }^{12}$ namely, Spanish coño,

\footnotetext{
11 «To confuse matters, in black American slang, a cock may be a vagina. The cockpit, meaning the vagina viewed sexually, puns on the site of avian contest» (Holder, 2003: 70. Original italics). Professor Keith Allan informed us (personal communication) that cock (meaning 'vagina') is also used among southern whites.

${ }^{12}$ While their etymologies in the other languages is clear, the etymology of English cunt is pretty obscure and for such a reason it remains under discussion: «Possibly derived from the Anglo-Saxon cynd, the Middle English form of the word was kunte, the same form used in Dutch and other languages. It is clearly related to the Icelandic kunta, and there can be little doubt that both are derived from a word which must have existed in a common Germanic language over two thousand years ago. This ancient language was itself evolved as an offshoot of another, older, language known as Proto-Indo-European, which probably existed between four and six thousand years ago. Philologists believe that in this language the sound $k u$ may have been used to mean much the same as the modern English cunt, and that indeed the word cunt is ultimately derived from it. This being so, we might reasonably expect to find similar derivatives in other Indo-European
} 
Catalan cony, Galician and Portuguese cona, Italian conno, and French con. All of them derive from Latin cunnus [rabbit], which in classical Latin was a semi-lexicalized metaphor and for such a reason Cicero recommended orators do not say cum nobis but nobiscum. ${ }^{13}$

Since the stage of lexicalization of a given metaphor depends on the different sociolects, dialects and/or idiolects and, in order to achieve a homogenous account, we will mainly refer to semi-lexicalized metaphors in this paper. And also, in order to achieve this homogenous account we will consider that a given metaphor is lexicalized or semi-lexicalized in Polish and Spanish when it is included in the Stownik polszczyzny potocznej (SPP, hereinafter) and in the Diccionario de la lengua española, for Polish and Spanish respectively. Similarly, since the Spanish language has many dialects most of them spoken in America, and in order to avoid painful and perhaps erroneous remarks, we will mainly focus our study on the standard dialect spoken in the Iberian Peninsula. So, we will only allude to examples from South American dialects occasionally and when they are included in the $D R A E$.

\section{NAMES OF ANIMALS, WHICH CAN BE USED AS INSULTS}

\subsection{Animal names referring to physical features of humans}

The animal metaphors naming human physical features and being considered as insults can be used with reference a) to both sexes, b) to women only, c) solely to men.

There are no such examples in the Polish corpus, which could be included in the first class (animal names referring to both sexes). The Spanish corpus contains twenty six examples of that kind, but eight of them are different names

languages. In fact there are a number of such languages which do have similar words: kun in Persian for example means rump or posterior, and the same word in Hittite meant tail. In Ancient Greek the word konnos also meant posterior. Another relation is the Latin cunnus, and thence the Italian conno and French con, all of which correspond in meaning to the English cunt». (McDonald, 1988: 35).

${ }^{13}$ «Quid, illud non olet unde sit, quod dicitur 'cum illis', 'cum' autem 'nobis' non dicitur, sed 'nobiscum'? quia si ita diceretur, obscaenius concurrent litterae, ut etiam modo, nisi 'autem' interposuissem, concurrissent. Ex eo est 'mecum' et 'tecum', non 'cum me' et 'cum te', ut esse simile illis 'nobiscum' atque 'vobiscum'.» (Cicero, Orator: XLVI, 154). 
for a pig (cf. cerdo/cerda; gorrino/gorrina; guarro/guarra; marrano/marrana; chancho/chancha; puerco/puerca; lechón/lechona [sucking pig], and verraco/verraca [male pig, boar]), and all of them signify in general 'dirty, filthy person'. Remaining examples focus on the short height and/or ugliness of a person, cf. gorgojo [weevil] 'midget, dwarf, small person', escarabajo [beetle] 'dwarf, stunted person', mico [monkey] 'short and very ugly person', sapo [toad] (El Salvador, Guatemala, Honduras, Mexico) 'short person', loro [parrot] 'very ugly person', and overweight, cf. mastodonte [mastodon] 'big/fat person', vaca [cow] 'fat man/woman'. ${ }^{14}$

The second class contains animal names, which are used only with regard to women. There are six examples from the Polish corpus and eight from Spanish. The analyzed names emphasize mostly ugliness. In the case of Polish examples women described by the animal names are ugly because they are fat and shapeless, cf. krowa [cow] 'shapeless woman, languid' (SJPSz), klępa [female elk] 'a woman who is languid and shapeless, untidy, sloppy' (SJPSz) or strangely dressed, cf. koczkodan [guenon] 'ugly woman, strangely dressed' (SJPSz), wydra [otter] 'a woman who is provocatively dressed' (SJPSz). Spanish examples stress that the woman is ugly and very thin, cf. arpia/harpia [harpy] 'ugly and skinny woman', penco [hack, nag] (Cuba) 'ugly and extremely thin woman'. There are examples in both languages which emphasized woman's sloppiness, cf. fladra [flounder] 'dirty, sloppy woman' (SJPSz), pava [turkey-hen] 'dirty (and dull) woman'. In addition, in Spanish and Polish examples can be found which mean woman who is old and ugly, cf. ropucha [toad] 'an old woman, who is stout, languid, ugly, not attractive' (SJPSz), cacatúa [cockatoo] 'ugly, old woman'. In Spanish furthermore some names of animals can signify young woman, e.g. bicha, [snake] 'girl' (El Salvador, Honduras), cabra [goat] 'girl' (Chile), polla [young hen] 'young woman'.

The third class assembles names of animals which are applied to men. The Polish corpus provides us seven examples of such a kind, while the Spanish one provides four lexemes. Two Polish words describe the age of a subject: szczeniak [puppy] 'someone young, usually young boy, a child, a whippersnapper' (SJPSz) and cap [billy goat] 'old man' (SPP). Another Polish example stresses the large size of a man, cf. byk [bull] 'big, stout, strong man' (SJPSz), stoń [elephant] 'huge man, languid, obese, clumsy' (SJPSz), wieprz [hog] 'fat man' (SJPSz). One lexeme

\footnotetext{
${ }^{14}$ Although not included in the DRAE, vaca is frequently used to mean a fat person, particularly a woman, at least in Spain.
} 
refers to a skinny man, cf. szczurek [little rat] 'about a man with thin, narrow, small face; someone small, skinny' (SJPSz). The last example from the Polish corpus emphasizes the sloppiness, cf. świntuch [derivative from śrwinia - 'pig'] 'dirty, sloppy man' (SJPSz). In the case of the Spanish material two lexemes also describe the age of a person, e.g. bicho [beast, bug] 'boy' (El Salvador, Honduras), pollo [chicken] 'youngster'. In the next two cases different features of a man are essential. The lexeme macaco [macaque] signifies 'ugly and deformed man' (Bolivia, Chile, Cuba), name tagarote [sparrow hawk] in one of its meanings is used to describe a man, with long legs.

Summing up, the animal names which signify physical features of a human being emphasize usually: sloppiness and ugliness (especially distortion of a figure e.g. shortness, shapeless body - too fat or too thin; old age and, more seldom, a peculiar way of dressing). Animals which are used in metaphors can be classified as follows, see table 1:

TABLE 1.

\begin{tabular}{|c|c|c|c|c|c|c|c|}
\hline \multicolumn{8}{|c|}{ Polish corpus } \\
\hline \multicolumn{5}{|c|}{ Wild animals (7) } & \multicolumn{3}{|c|}{ Domestic animals (6) } \\
\hline Insects & $\begin{array}{c}\text { Sea } \\
\text { animals }\end{array}$ & $\begin{array}{l}\text { Amphibians/ } \\
\text { reptiles }\end{array}$ & Birds & Mammals & $\begin{array}{l}\text { Which are } \\
\text { bred for } \\
\text { milk/meat }\end{array}$ & $\begin{array}{l}\text { Which are bred for } \\
\text { reproduction } \\
\text { purposes }^{15}\end{array}$ & $\begin{array}{l}\text { Which are } \\
\text { bred for } \\
\text { other } \\
\text { reasons }\end{array}$ \\
\hline- & 1 & 1 & - & 5 & 2 & 3 & 1 \\
\hline \multicolumn{8}{|c|}{ Spanish corpus ${ }^{16}$} \\
\hline \multicolumn{5}{|c|}{ Wild animals (17) } & \multicolumn{3}{|c|}{ Domestic animals (13) } \\
\hline Insects & $\begin{array}{c}\text { Sea } \\
\text { animals }\end{array}$ & Amphibians/reptiles & Birds & Mammals & $\begin{array}{l}\text { Which are } \\
\text { bred for } \\
\text { milk/meat }\end{array}$ & $\begin{array}{l}\text { Which are bred for } \\
\text { reproduction } \\
\text { purposes }\end{array}$ & $\begin{array}{l}\text { Which are } \\
\text { bred for } \\
\text { other } \\
\text { reasons }\end{array}$ \\
\hline 4 & 1 & 3 & 4 & 6 & 13 & 1 & 1 \\
\hline
\end{tabular}

\subsection{Animal names referring to pudenda and sexual activity}

The next class of analyzed animal names refers to pudenda of a man and human sexual activity. The group which will be described here as the first one contains lexemes naming human organs.

There are five names of pudenda in Polish and six examples of that kind in the Spanish corpus. Three Polish lexemes signify 'penis', e.g. dziobak [platypus]

\footnotetext{
${ }^{15}$ E.g. bull, stallion, etc.

${ }^{16}$ In the table were not taken into consideration examples of animals which are extinct, e.g. mastodon and mythological creatures, e.g. harpy and tarasca.
} 
(SPPW), koń [horse] (SPPW), ptak [bird]/ptaszek [diminutive form] (SPP) and two are names of women's organs, cf. cipka [young hen]/ cipa [augmentative form] 'vagina' (SPPW), kot [cat] 'hair on a woman's pubes' (SPP). In the case of Spanish three lexemes refer to penis, e.g. pájaro [bird] (Guatemala, Venezuela), paloma [dove] (Central America, Venezuela), polla [young hen]. ${ }^{17}$ Also three animal names in Spanish are used for a woman's pudendum, cf. gallo [cock, rooster] 'clitoris' (El Salvador), mico [monkey] 'vagina' (Costa Rica, El Salvador, Guatemala, Nicaragua), paloma [dove] 'vulva' (Guatemala).

The group of lexemes which signifies human sexual activity is very diverse. Therefore it will be described in the following order: a) animal names referring to women, b) animal names referring to men.

There are four examples in Polish which mean female sexuality. Two of them signify 'whore, prostitute', cf. fladra [flounder] 'whore' (SJPSZ), mewka [diminutive form derived from mewa - 'seagull'] 'whore, in port city' (SJPSz). Another two animal names refer to a woman, which is not a professional prostitute, but is very attractive sexually and promiscuous, e.g. samica [animal female] (SJPSz), suka [bitch] (SPPW). In the Spanish corpus were found ten examples which mean woman's sexual activity, but six of them are names for a prostitute, e.g. araña [spider] 'whore', perra [bitch] 'whore', zorra [vixen] 'whore'. Two lexemes describe a femme fatal, a woman who seduces men, cf. tigresa [tigress] 'vamp, femme fatale', vampiresa [she-vampire bat] 1 'vamp' 2 'femme fatale'. One example is referred to a young woman, a girlfriend, cf. bicha [snake] 'girlfriend' (El Salvador).

The next group contains animal names which signify male sexual activity. In Polish only one such word was found, cf. samiec [animal male] (SJPSz) - that lexeme in its metaphorical meaning refers to a promiscuous, lustful man. There are ten examples of that kind in the Spanish corpus, six of them signify a homosexual, e.g. ganso [gander, goose] 'queer, pouf' (Cuba), mula [mule] 'queer, pouf' (Cuba), pato [duck] 'queer, pouf' (Antilles, Nicaragua, Venezuela). Two animal names are applied to a man, who is a procurer, cf. cabrón [he-goat] 'pimp' (South America), chivo [kid, baby/young goat] 'pimp' (Nicaragua). The lexeme

\footnotetext{
${ }^{17}$ Although in Spain polla is an extremely bawdy word, it means 'lottery' or 'wager' in America («apuesta, especialmente en carreras de caballos») and, obviously it is not a bawdy word at all.
} 
capón [capon] means a castrated man and the word mico [monkey] is applied to a lustful man.

There are three lexemes (one Polish and two Spanish) in the analyzed class, which do not exactly signify sexual activity of a subject, cf. rogacz [stag] 'a man, whose wife is unfaithful, a cuckold' (SJPSz), novillo [young bull] 'cuckold', cabrón/cabrona [he-goat] 'cuckold'. They were included in the discussed class because the subject is victim of the sexual activity of the spouse.

The analyzed material shows that animal names are used mainly for the description of a sexual behavior which is considered as not being consistent with the norm established in a society and therefore not accepted, e.g. homosexual love, female professional prostitution and promiscuity of women and (rarely) of men. Examples which signify a man (rarely a woman) whose wife is unfaithful can be found in both languages.

Animals which are used in described metaphors can be classified as follows, see table 2:

TABLE 2

\begin{tabular}{|c|c|c|c|c|c|c|c|}
\hline \multicolumn{8}{|c|}{ Polish corpus } \\
\hline \multicolumn{5}{|c|}{ Wild animals (5) } & \multicolumn{3}{|c|}{ Domestic animals (6) } \\
\hline Insects & $\begin{array}{c}\text { Sea } \\
\text { animals }\end{array}$ & Amphibians/reptiles & Birds & Mammals & $\begin{array}{l}\text { Which are } \\
\text { bred for } \\
\text { milk/meat }\end{array}$ & $\begin{array}{l}\text { Which are bred } \\
\text { for reproduction } \\
\text { purposes }\end{array}$ & $\begin{array}{l}\text { Which are } \\
\text { bred for } \\
\text { other } \\
\text { reasons }\end{array}$ \\
\hline- & 1 & - & 1 & 3 & 1 & - & 4 \\
\hline \multicolumn{8}{|c|}{ Spanish corpus } \\
\hline \multicolumn{5}{|c|}{ Wild animals (14) } & \multicolumn{3}{|c|}{ Domestic animals (13) } \\
\hline Insects & $\begin{array}{c}\text { Sea } \\
\text { animals }\end{array}$ & Amphibians/reptiles & Birds & Mammals & $\begin{array}{l}\text { Which are } \\
\text { bred for } \\
\text { milk/meat }\end{array}$ & $\begin{array}{l}\text { Which are bred } \\
\text { for reproduction } \\
\text { purposes }\end{array}$ & $\begin{array}{l}\text { Which are } \\
\text { bred for } \\
\text { other } \\
\text { reasons }\end{array}$ \\
\hline 3 & - & 2 & 2 & 6 & 5 & 3 & 4 \\
\hline
\end{tabular}

In the described class lots of words contain information about the animal's sex (which is not always compatible with the sex of a subject), e.g. rogacz [stag] 'a man, whose wife is unfaithful, a cuckold' (SJPSz), samica [female] (SJPSz), suka [bitch] (SPPW), perra [bitch] 'whore', yegua [mare] 'queer, pouf' (Cuba), zorra [vixen] 'whore', cabrón [he-goat] 'pimp' (Southern America). The analyzed class also contains names of animals which were castrated, e.g. capón [capon] 'castrated' or 'infertile' e.g. mula [mule] 'queer, pouf' (Cuba). 


\subsection{Animal names naming features of human character}

The following class of animal names contains lexemes which refer to human mental and psychological features. There are words, similar to those in the classes described above, can be applied to both sexes, to women only or exclusively to men.

In the Polish corpus animal names which can refer to men or women are quite rare - only nine examples were found, e.g. the word świnia [pig] means 'someone mean, obscene' (SJPSz), gadzina [derivative from gad - 'reptile'] refers to 'someone mean' (SJPsz), biena [hyena] signifies 'someone ruthless, exploiting suffering people' (SJPSz), papuga [parrot] 'someone thoughtlessly echoing sb's words' (SJPSz), ptotka [cockroach] 'insignificant person, being low in a hierarchy, small fry' (SJPSz). The Spanish material is much more extensive. There are as many as eighty seven examples of animal names which can be used with a reference to both sexes. Most analyzed words signify brutality, meanness and aggression, e.g. animal [animal] 'brute, lout, beast', fiera [wild animal, beast] 'brute, cruel person', biena [hyena] 'brute', lagarto [lizard] 'mean person' (Nicaragua), marrajo [mako shark] 'malicious person'. Lots of Spanish examples in the described group mean foolishness, e.g. yegua [mare] 'idiot, stupid' (Central America, Puerto Rico), percebe [goose barnacle] 'idiot, twit', besugo [sea bream] 'idiot, drip, twerp'. Another quite big set of animal names refer to persons who are boring and obtrusive e.g. abejorro [bumblebee] 'bore, nuisance', lapa [limpet] 'bore', mosca [fly] 'bore, nuisance, pest', pato [duck] 'drip, bore, dull person'. Also quite often in animal metaphors are emphasized features such as cunning, cf. caimán [caiman/alligator] 'sly old fox', loquaciousness, e.g. cotorra [parrot, magpie] 'chatterbox, windbag', cowardice, e.g. liebre [hare] 'shy and coward person'.

The next group contains animal names which can be applied to women only. In the Polish corpus nine examples were found. Three of them generally mean stupidity, cf. gęś [goose]/gaska [diminutive form] 'slow-witted, naive, stupid woman' (SJPSz), krowa [cow] 'stupid woman' (SJPSz), kura [hen] especially kura domowa [home hen] 'a woman, who is interested only in house work, who is narrow-minded, a homebody' (SJPSz). Two examples signify malice, e.g. żmija [viper]/żmijka [diminutive form] 'bad, sneaky woman' (SJPSz), matpa [monkey]/matpiszon [a derivative] 'malicious person' (SJPSz). The word reydra [otter] refers to 'cunning, quarrelsome woman' (SJPSz) and the lexeme kwoka [broodhen] means metaphorically 'unbearable, bothersome, grumbling woman' 
(SJPsz). Two animal names signify young girls, e.g. kociak [kitten] 'chick' (SJPSz), koza [goat] 'about lively, cheerful, young girl' (SJPSz).

There are six examples of such a kind in the Spanish corpus. Two of them are used with a reference to an impolite woman, cf. burra [she-donkey] 'rude woman', yegua [mare] 'rude woman' (Cuba, Uruguay). The rest animal names signify different unwanted features of female character, e.g. borrica [she-donkey] 'stupid woman', lagarta [female lizard] 'sly woman, sly minx', tigresa [she-tiger] 'furious, angry woman'.

The last group of animal names signifying human mental or psychical features contains lexemes which refer only to men. In the Polish corpus thirty two examples of that kind were found. Most of them refer to a mean, evil person, who has done something wrong to the speaker, e.g. padalec [blindworm] 'mean man' (SPP), bestia [beast] 'bad, cruel, degenerate man' (SJPSz), gad [reptile] 'mean, insincere, man' (SJPSz), bydle [cattle] 'worthless, thoughtless, mean man' (SJPSz). Some animal names mean a stupid and/or naïve man, cf. jeleń [(red) deer] 'naive, gullible, resourceless man, sucker' (SJPSz), mut [mule] 'stupid man' (SPP), dudek [hoopoe] 'fool' (SJPSz), baran [ram] 'stupid man, idiot' (SJPSz). There are also examples which in general signify immorality of a person, e.g. gnida [nit] 'inconspicuous man, who from hiding is detrimental to someone, morally disgusting' (SJPSz), świntuch [derivative from świnia - 'pig'] 'immoral, indecent man' (SJPSz), cap [billy goat] 'old man, lecher' (SPP). Some animal names are used with a reference to a man whose behavior arouse disgust, abomination, because of his weakness mięczak [mollusk] 'weak man, wimp' (SJPSz), being a exploiter, e.g. pasożyt [parasite] 'a man who lives at the cost or expense of somebody, a sponger' (SJPSz), szakal [jackal] 'man drawing profits out of someone's misfortunes, exploiter' (SJPSz), rekin [shark] 'financial potentate, ruthless in business, destroying weak' (SJPSz), behaving with no dignity, cf. ptaz [amphibian] 'a man who to crawls to somebody' (SJPSz).

There are twenty one examples of the described type in the Spanish corpus. A significant number emphasize male cunning, cf. zorro/zorra [fox] 'sly person', rodaballo [turbot] 'sly old fox', pollo [chicken] 'sly old fox', lagarto [lizard] 'sly devil, crafty fellow'. Similar to the Polish material, there are some examples in Spanish which signify stupidity of a man, e.g. macho [he-mule] 'stupid man', merluzo [hake] 'ninny, silly man' and brutality, rudeness and aggression, e.g. rocin [hack, nag] 'rude, brute man', atún [tuna fish] 'rude, brute'. Other features of male character which can be found it the Spanish corpus of animal names are: lasciviousness, e.g. gallo [cock, rooster] 'cocky man', tórtolo [male turtle-dove] 
'lovebird', being a bore, cf. pavo [turkey] 'dull or unwary man', moscardón, [botfly, blowfly] 'bore, nuisance, pest', drunkenness, e.g. mosquito [mosquito] 'man who visits taverns frequently' and loquaciousness, e.g. loro [parrot] 'chatterbox' (El Salvador, Peru, Uruguay).

In the case of the described class of animal names the most frequent mental and psychical features of a human are: a) for the Polish corpus - stupidity, meanness and immorality, b) for the Spanish corpus - cunning, stupidity, meanness and being a bore. The animal used as vehicle in the metaphors are classified in table 4:

TABLE 4

\begin{tabular}{|c|c|c|c|c|c|c|c|}
\hline \multicolumn{8}{|c|}{ Polish corpus } \\
\hline \multicolumn{5}{|c|}{ Wild animals (29) } & \multicolumn{3}{|c|}{ Domestic animals (21) } \\
\hline Insects & $\begin{array}{c}\text { Sea } \\
\text { animals }\end{array}$ & Amphibians/reptiles & Birds & Mammals & $\begin{array}{l}\text { Which are } \\
\text { bred for } \\
\text { milk/meat }\end{array}$ & $\begin{array}{c}\text { Which are bred } \\
\text { for reproduction } \\
\text { purposes }\end{array}$ & $\begin{array}{l}\text { Which are } \\
\text { bred for } \\
\text { other } \\
\text { reasons }\end{array}$ \\
\hline 3 & 3 & 6 & 6 & 12 & 10 & 4 & 7 \\
\hline \multicolumn{8}{|c|}{ Spanish corpus ${ }^{18}$} \\
\hline \multicolumn{5}{|c|}{ Wild animals (80) } & \multicolumn{3}{|c|}{ Domestic animals (29) } \\
\hline Insects & $\begin{array}{c}\text { Sea } \\
\text { animals }\end{array}$ & Amphibians/reptiles & Birds & Mammals & $\begin{array}{l}\text { Which are } \\
\text { bred for } \\
\text { milk/meat }\end{array}$ & $\begin{array}{l}\text { Which are bred } \\
\text { for reproduction } \\
\text { purposes }\end{array}$ & $\begin{array}{l}\text { Which are } \\
\text { bred for } \\
\text { other } \\
\text { reasons }\end{array}$ \\
\hline 17 & 13 & 10 & 20 & 20 & 12 & 3 & 14 \\
\hline
\end{tabular}

\subsection{Animal names referring to groups of people}

Another class of animal names, which can be used as insults, contains lexemes which signify groups of people. There are only two such examples in the Polish corpus - bydto [cattle] 'critically about group people' (SJPSz), szarańcza [locust] 'about crowd, especially destroying something' (SJPSz) and six such examples in Spanish - most of them refer to an indeterminate crowd, cf. ganado [cattle] 'crowd, people', marabunta [plague of ants] 'crowd', hatajo [small herd/flock] 'bunch of people', jauria [pack of hounds] 'group of people'. Some words have more specific reference, e.g. perrería [pack of dogs] 'gang', tórtolos [male turtledoves] 'lovebirds, couple of lovers'. Names belonging to the described class signify in their primary meaning a group of animals: domestic (herd, pack of dogs) or wild (ants, turtledoves). The lexeme cattle in Polish has the very strong connotation of thoughtlessness and stupidity. The pack of dogs is usually used

${ }^{18}$ Mythological monsters and animal e.g. harpy are not taken into consideration. 
for hunting, which makes one think of a virulent, bloodthirsty chase after a victim. Ants in big clusters can be damaging for people.

\subsection{Animal names referring to human jobs or occupation}

The next class of animal names used as insults assembles words which mean human jobs or (more general) occupation. There are four examples of that kind in the Polish corpus and twenty nine lexemes in Spanish. It is quite obvious that analyzed lexemes refer in principle to jobs or occupation which are undesirable, unwelcome in a society: in the case of the Polish material it is the prostitution, c.f. fladra [flounder] 'whore' (SJPsz), mewka [diminutive form of mewa 'seagull'] 'a whore, in port city' (SJPSz) and the thieving, cf. biena [hyena] especially biena cmentarna 'a thief, who robs graves' (SJPSz). The last Polish example goryl means 'bodyguard'. Spanish lexemes signify in most cases prostitution, e.g. zángana [drone] 'whore' (Nicaragua), penco [hack, nag] 'whore' (Canary Islands) ${ }^{19}$, being an informer, cf. chiva [young goat] 'informer' (Cuba), papagayo [parrot] 'informer', rana [frog] 'informer' (Colombia), the thieving, e.g. garduño/garduña [marten] 'sneak thief, pickpocket', gato/gata [he-cat/she-cat] 'sneak thief', rata [rat] 'thief', piraña [piranha] 'thief who acts with others' (Peru), being a smuggler, cf. camello [camel] 'drug pusher', mula [she-mule] 'drug pusher' (Ecuador, Colombia).

Animals used as vehicles in the described metaphors can be classified as follows (see table 5):

TABLE 5

\begin{tabular}{|c|c|c|c|c|c|c|c|}
\hline \multicolumn{8}{|c|}{ Polish corpus } \\
\hline \multicolumn{5}{|c|}{ Wild animals (4) } & \multicolumn{3}{|c|}{ Domestic animals (0) } \\
\hline Insects & $\begin{array}{c}\text { Sea } \\
\text { animals }\end{array}$ & Amphibians/reptiles & Birds & Mammals & $\begin{array}{l}\text { Which are } \\
\text { bred for } \\
\text { milk/meat }\end{array}$ & $\begin{array}{c}\text { Which are bred } \\
\text { for reproduction } \\
\text { purposes }\end{array}$ & $\begin{array}{c}\text { Which are } \\
\text { bred for } \\
\text { other } \\
\text { reasons }\end{array}$ \\
\hline- & 1 & - & 1 & 2 & - & - & - \\
\hline \multicolumn{8}{|c|}{ Spanish corpus } \\
\hline \multicolumn{5}{|c|}{ Wild animals (21) } & \multicolumn{3}{|c|}{ Domestic animals (8) } \\
\hline Insects & $\begin{array}{c}\text { Sea } \\
\text { animals }\end{array}$ & Amphibians/reptiles & Birds & Mammals & $\begin{array}{l}\text { Which are } \\
\text { bred for } \\
\text { milk/meat }\end{array}$ & $\begin{array}{c}\text { Which are bred } \\
\text { for reproduction } \\
\text { purposes }\end{array}$ & $\begin{array}{l}\text { Which are } \\
\text { bred for } \\
\text { other } \\
\text { reasons }\end{array}$ \\
\hline 3 & 1 & 3 & 7 & 7 & 2 & 1 & 5 \\
\hline
\end{tabular}

${ }^{19}$ Compare also class of animal names referring to human sexual activity and pudenda. 


\subsection{Animal names referring to human secretions, diseases, injuries, and} intoxications

The next group of animal names contains lexemes which metaphorically refer to human secretions, sicknesses, states of ill-being. There are only two examples of that kind in the Polish corpus, e.g. gil [bullfinch] 'secretion flowing from the nose', paw [peacock] 'products of vomiting', cf. idiom puścić pawia 'to puke'. The Spanish material is much larger - there are sixteen examples of animal names which mean human ill-being. Most of them refer to a state of intoxication, cf. lobo [wolf] 'drunkenness', mona [she-monkey] 'drunkenness', merluza [hake] 'drunkenness', perra [she-dog] 'drunkenness', ratón [mouse] 'hangover' (Venezuela).

\section{NAMES OF ANIMAL BODY PARTS, SECRETIONS AND ACTIONS WHICH CAN BE USED AS INSULTS}

\subsection{Names of animal body parts referring to humans}

There are fourteen examples of Polish lexemes which primarily signify animal body parts and can be used as insults. Most of them refer to the human head and its parts. Three names of animal body parts mean human face, cf. morda [muzzle] (SPPW), pysk [muzzle] (SPPW), ryj [snout] (SJPSz). Two examples signify the human mouth, e.g. paszcza [jaws] (SJPSz), dziób [beak] (SPP). There are also two words which mean human tongue, cf. jezzor [about animal tongue] (SJPSz), ozór [about animal tongue] (SJPSz). One lexeme refers to the human head, cf. teb [animal head] (SJPSz) and the last one signify human teeth, e.g. kty [fangs] (SPP). Two examples are applied to human buttocks, cf. kuper [rump of a bird] 'bottom' (SJPSz), zad [rump] 'fat bottom' (SJPSz). The word tapa [paw] signifies the human hand (SPP), the lexeme ogon [tail] refers to the human penis $(S P P W)$ and the last example - kopyto [hoof] means 'human leg' $(S J P S z)$.

The Spanish corpus contains thirteen examples which can be rated among the analyzed class, but most of them have multiple meanings. Five of the lexemes signify different parts of the human head, cf. concha [shell, tortoiseshell] 'cheek' (Ecuador, Peru), hocico [snout, muzzle] 1) 'bubbler lips' 2) 'face', jeta [snout] 1) 'human face' 2) 'cheek', pechuga [breast (of fowl)] 'cheek' (Ecuador, Panama, Peru), pico [beak] 'mouth'. Three examples refer to the human buttocks, e.g. anca [haunch] 'bottom', cola [tail] 'buttocks, bottom' (Argentina, Colombia, Uruguay), rabo [tail] 'bottom, bum' (Colombia, Costa Rica, Venezuela). A 
relatively big group of analyzed names of animal body parts mean different human sexual organs: the female bosom can be described as buche [craw] or pechuga [breast (of fowl)]; to the male penis are applied such lexemes as pico [beak] (Chile, Costa Rica) and rabo [tail]; to the woman's pudenda the word concha [shell, tortoiseshell] 'cunt' (Argentina, Chile, Peru, Uruguay) ${ }^{20}$ is applied; to other parts of the human body the following Spanish names of animal body parts are applied, cf. anca [haunch] 'hip', buche [craw] 'belly, stomach', pata [leg] 'leg'. The Spanish corpus contains some examples which do not signify man's limbs, e.g. pluma [feather] 'fart', pécora [head of (sheep) cattle] 'whore', raspa [backbone (fish)] 'someone unfriendly, unpleasant'.

The described class of names which literally mean animal body parts contains lexemes which in most cases metaphorically refer to human body parts. The head and its parts are the most frequent targets in the analyzed Polish and Spanish corpora. Probably the reason is that the human head, especially the face, is the most important element of our body, because it gathers most features which let other people identify a person. Less frequently, but still quite numerous are names for buttocks and human pudenda. Only few names refer to the human arms, legs and stomach.

\subsection{Names of animal secretions referring to human}

The class of lexemes which signify animal secretions is relatively small, but it seems that using that kind of names as an insult is quite common in various languages, not only Spanish and Polish - it is not surprising, because animal secretions can arouse disgust in people. There are three such example in the Polish lexicon, cf. gnój [manure] 'shitface' (SJPSz), ścierwo [carcass] 'bastard' (SJPSz) and jajko/jajo [egg] 'testicle' (SJPSz). The Spanish corpus contains as well three lexemes which literally mean animal secretions and can be used with a reference to a human as an insult, e.g. capullo [cocoon] means both 'prepuce, head (of the penis)' and 'novice, beginner', ${ }^{21}$ carroña [decaying carcass, carrion] 'trash (people)', buevo [egg] also means both 'testicle, ball' and 'ninny' (Uruguay). In both languages names of dead, decomposing animals signify an evil, morally disgusting person or people. Also both Spanish and Polish lexemes

${ }^{20}$ Concha is a bawdy word in America (particularly in Argentina). By contrast, it is not a bawdy word at all in Spain. In Spain Concha is only the nickname for Concepción.

${ }^{21}$ Although not included in the DRAE, capullo is usually used as a derogatory term meaning 'stupid' or 'ninny'. 
that mean 'egg' have the metaphorical sense of male testicles as well, which is probably motivated by a likeness in shape.

\subsection{Names of animal states, behavior and sounds used as insults}

Another class of lexemes concerning animals, which can be used as insults, contains names which signify literally animal states, behavior, sound made by them and also names of actions of people aimed at animals. There is a relatively big group of such examples in the Polish corpus - thirty three lexemes. In the first group there are verbs which name sounds made by animals, e.g. bzykać (sie) [to hum] 'to have sex (with somebody)' (SPPW), gdakać [to cackle] 'to prattle, to grouch' (SJPSz), gęgać [to garggle] 1) 'to talk thorough a nose, to talk gibberish', 2) 'to talk mindlessly or boringly' (SJPSz), szczekaćl obszczekaćl oszczekać [to bark] 'to backbite, to defame, to vilify someone; to lie, to make up things', odszczekać [to bark back] 1) 'to answer impolitely, in a surly manner; to retort', 2) 'to withdraw something unfair that was said about someone' (SJPSz). Another group of analyzed words gathers verbs which mean literally behavior and states of animals, cf. chlaćl żtopać [about animals - to drink] 'to booze' (SJPSz), żreć [about animals - to eat] 'to gobble' (SJPSz), gzić sie [about some animals - by anxious behavior show sexual drive; to satisfy sexual drive] 'to make love' (SJPSz), podziobać [to peck] 'to make love' (SPPW), trykać [about goats - to butt] 'to make love' (SPP), zdechnać [about animals - to die] 'to die' (SPPW). The last group contains verbs that signify actions taken by people and aimed at animals, e.g. dosiadać [to mount a horse] 'to make love' (SPPW), ktoś bije/rabie/trzepie/wali konia [to beat/ wallop/ spank/ strike a horse] 'to masturbate' (SPPW) (SPP), ktoś jedziel jeździ na koniu [to ride a horse] 'about a woman - to make love' (SPPW), rozkulbaczyć [to unsaddle a horse] 'to lose one's virginity' (SPPW), ujeżdżać [to break in a horse] 'to make love'(SPPW).

Comparing to the Polish material, the Spanish lexemes which can be rated among the described class are few - only seven examples and most of them signifying sounds made by animals, cf. berrear [to low (calves)]: 1) 'to cry', 2) 'to bawl', 3) 'to declare, to confess', cacarear [to cluck]: 'to strut about, to boast about', bufar [to snort] 'to snort with rage', ladrar [to bark] 1) 'to threaten', 2) 'to accuse, to brand', mugir [to low, to moo, to bellow] 'to bellow, to roar', piar [to cheep, to chirp, to peep] 1) 'to protest, to grouse', 2) 'to drink wine'.

Onomatopoeia in most cases signifies sounds made by people (cry, laugh, singing, etc.), cf. beczeć [to bleat] 1) 'to sing terribly', 2) 'to cry loudly', rechotać 'to laugh loudly, hoarsely, coarsely', mugir [to low, to moo, to bellow] 'to 
bellow, to roar', bufar [to snort] 'to snort with rage', berrear [to low (calves)] 'to cry'. Some onomatopoeia refers to the way people speak, mruczeć [to purr] 'to murmur', skomleć [to whine] 'piteously, obtrusively ask for something, to groan, to complain', świergotać [to twitter] 'about children, young women, to speak merrily, gently', warczeć 'to grunt, to speak in a surly manner'.

A relatively substantial group of described lexemes which signify literally sounds made by animals is used metaphorically with the reference to the content of what the person is saying, cf. krakać [to croak] 'to express gloomy expectations, to foretell evil, to croak', szczekać/ obszczekać/ oszczekać [to bark] 'to backbite, to defame, to vilify someone; to lie, to make up things', cacarear [to cluck] 'to boast about', berrear [to low (calves)] 'to declare, to confess', ladrar [to bark] 1) 'to threaten', 2) 'to accuse, to brand'.

Very few onomatopoeias mean human actions other than speaking or making sounds, e.g. bzykać (sie) [to hum] 'to have sex (with somebody)' (SPPW), piar [to cheep, to chirp, to peep] 'to drink wine'.

Most examples belonging to the group of lexemes which literally mean actions and states of animals in most cases signify human sexual behavior, cf. gzić sie [about some animals - by anxious behavior show sexual drive; to satisfy sexual drive] 'to make love' (SJPSz), podziobać [to peck] 'to make love' (SPPW), trykać [about goats - to butt] 'to make love' (SPP). A few examples refer to consuming food or drink, e.g. żreć [about animals - to eat] 'to gobble' (SJPSz), chlać/ żtopać [about animals - to drink] 'to booze' (SJPSz).

\section{DERIVATIVES OF ANIMAL NAMES USED AS INSULT}

Animal names can also serve as a base for derivation of other nouns, verbs and adjectives, which in most cases are offensive and can be used as insults. There are thirty five of such examples in the Polish corpus. The analyzed lexemes refer in most cases to a particular feature of a person (mental or physical) and in most cases their meaning is very close to the metaphorical senses of nouns, which are the bases for the derivation, e.g. verbs: capić [cap -billy goat] 'to smell disgusting' (SPP), świnić (sie)/ oświnić/ześwinić się/ świntuszyć [świnia -pig] 1) 'to dirty, to soil' 2) 'to play a dirty or rotten trick on somebody; to say dirty words'(SJPSz), zezwierzęcieć [zwierzę -animal] 'to become mean like animal, not to behave like a man' (SJPSz), matpowaćl zmatpować [matpa -monkey] 'to copy, to emulate someone mindlessly' (SJPSz), pasożytować [pasożyt - parasite] 'to live at somebody's expense, be a sponger; adjectives: cielecy [ciele - calf] 'naive, not very smart', jaszczurczy [jaszczurka - lizard] 'full of evil susceptibility, mean, wicked, 
malicious', pieski [pies - dog] 'miserable, bad, paltry'. Only one example in Polish is distinguished by its meaning in the analyzed group, cf. gzić sie [giez horsefly] [about some animals - by anxious behavior show sexual drive; to satisfy sexual drive] 'to make love' (SJPSz).

The Spanish corpus includes forty four examples of such kind and, as in Polish, the derivatives most often are very close to the metaphoric meaning of the animal names which are the base for derivation, e.g. verbs acochinar [cochino/cocbina - pig] 1) 'to kill, to bump off (someone unable to defend him/herself)', 2) 'to frighten', 3) 'to acquire dirty habits (moral and physical)', cotorrear [cotorra - parrot, magpie] 'to chatter, to prattle away', gallear [gallo cock/rooster] 1) 'to brag', 2) 'to put on airs and graces, to be arrogant', 3) 'to get furious and swear', gansear [ganso/gansa - gender/goose] 'to do/say daft things'; nouns, e.g. animalada [animal -animal] 'stupid/bawdy thing to do or say, piece of nonsense', asnada/asnería [asno/asna - donkey] 'silliness', adjectives, cf. aborregado/aborregada [borrego/borrega - yearling lamb] 'sheeplike, mindless', pavisoso/pavisosa [pavo/pava - turkey] 'silly, stupid, foolish, ninny, nincompoop, fool'.

\section{CONCLUSIONS}

As Ryszard Tokarski writes "Metaphors of animal names almost regularly introduce negative evaluation and only in a few examples carry positive emotional load [...]. And yet definitely most animal names, which are used metaphorically, evaluate negatively [...]. Very regular negative evaluation of the animal world surely on the one hand is the result of the influence of human knowledge and experience. But on the other hand it is the effect of the more general human attitude towards the world. A man places himself in the centre of the world, and categorization and evaluation of the world are made relative to this centre. A man as the central element of the world is the best living being, the world outside humankind must be worse" (Tokarski 1991, 150-151) [tranls. mine M.Z].

The analyzed lexical material from two languages - Polish and Spanish shows how extensive and diverse the class of animal names is, which can be used as an insult. In the article we described nouns referring to different kinds of animals (insects, fishes, amphibians, reptiles, mammals - wild and domestic), names of animal body parts, animal behavior and secretions, derivatives from animal names (nouns, adjectives, verbs). 
The class which includes names of animals is the largest one. Examples from the Spanish corpus outnumber Polish lexemes. The animal species used as vehicles in the described metaphors are as follows (see table 6):

TABLE 6

\begin{tabular}{|c|c|c|c|c|c|c|c|}
\hline \multicolumn{8}{|c|}{ Polish corpus } \\
\hline \multicolumn{5}{|c|}{ Wild animals (54) } & \multicolumn{3}{|c|}{ Domestic animals (32) } \\
\hline Insects & $\begin{array}{c}\text { Sea } \\
\text { animals }\end{array}$ & Amphibians/reptiles & Birds & Mammals & $\begin{array}{l}\text { Which are } \\
\text { bred for } \\
\text { milk/meat }\end{array}$ & $\begin{array}{l}\text { Which are bred } \\
\text { for reproduction } \\
\text { purposes }\end{array}$ & $\begin{array}{c}\text { Which are } \\
\text { bred for } \\
\text { other } \\
\text { reasons }\end{array}$ \\
\hline 7 & 6 & 7 & 12 & 22 & 13 & 7 & 12 \\
\hline \multicolumn{8}{|c|}{ Spanish corpus } \\
\hline \multicolumn{5}{|c|}{ Wild animals (132) } & \multicolumn{3}{|c|}{ Domestic animals (64) } \\
\hline Insects & $\begin{array}{c}\text { Sea } \\
\text { animals }\end{array}$ & Amphibians/reptiles & Birds & Mammals & $\begin{array}{l}\text { Which are } \\
\text { bred for } \\
\text { milk/meat }\end{array}$ & $\begin{array}{l}\text { Which are bred } \\
\text { for reproduction } \\
\text { purposes }\end{array}$ & $\begin{array}{c}\text { Which are } \\
\text { bred for } \\
\text { other } \\
\text { reasons }\end{array}$ \\
\hline 27 & 15 & 18 & 33 & 39 & 32 & 8 & 24 \\
\hline
\end{tabular}

The numbers show that in both languages wild animals are used much more often as vehicles in metaphors than domestic ones (cf. fifty four examples of wild animal names to thirty two names of domestic animals in the case of the Polish corpus; one hundred thirty two lexemes referring to wild animals to sixty four examples of domestic animal names in the case of the Spanish corpus). More often names of animals more distant from the human centre are used - less similar to man, that is not mammals: the Polish corpus includes only twenty two examples which signify wild mammals, whereas thirty two nouns refer to other species. In the case of Spanish the difference is even more striking - there are only 39 names of wild mammals in the Spanish corpus and 93 names of animals which are not mammals.

The analyzed material shows that for a vehicle in metaphors describing humans the following animals are chosen:

1. Wild animals, not useful ${ }^{22}$ to humans, e.g. reydra [otter], escarabajo [beetle], grajo [rook, crow], zángano [drone].

2. Pests, e.g. gorgojo [weevil], lirón [dormouse], marmota [marmot].

3. Dangerous animals, e.g. żmija [viper], tiburón [shark], tigre [tiger].

4. Animals (usually insects, amfibians and reptailes) disgusting for a man, e.g. ropucha [toad], sapo [toad], lagarto [lizard].

${ }^{22}$ Generally - comparing to domestic animals - wild animals are of course less or not at all useful for humans. 
5. Not prototypical examples of a category (because of their strange or/and funny look), e.g. klępa [female elk], fladra [flounder], koczkodan [guenon], cacatúa [cockatoo], macaco [macaque].

6. Domestic animals usually concidered as useful for humans, but treated only as source of eggs, milk and meat, e.g. krowa [cow], pava [turkey-hen], chancho/chancha [sow].

7. Domestic animals less useful for a man, kept only for reproductive purpose, e.g. byk [bull], cap [billy goat], verraco/verraca [male pig, boar].

8. Domestic animals useful for a man, but devoid of reproductive organs or infertile, e.g. macho [he-mule], capón [capon].

9. Animals which used to be useful or will be useful in the future, but now can not perform their duties, e.g. szczeniak [puppy], penco [hack, nag].

Another hereby described class of lexemes which refer to animals contains names of an animal body part, their secretions, verbs signifying animal behavior, or human actions taken towards animals. The interesting case is that both languages have words "worse", reserved only for animals. When such lexemes are used with a reference to human, they are always treated as an insult. As Zdzisław Kempf notices, In the number of terms signifying body parts and actions our language has introduced for animals 'worse' words, for people 'better', because a man umiera [dies], while an animal zdycha [dies - about animals]; a man je [eats], while an animal żre [eats - about animals]; a man has gtowe [head], while an animal teb [head - about animal], a man has a hand, while an animal a paw; a man has a face, while an animal a muzzle [...]. It's obvious that animal terms are pejorative, depreciating. That is confirmed by a fact that such words can be used with reference to people, but then those people are depreciated by us, and we emphasize our antipathy against them. Compare: żre jak świnia [eats [about animals] like a pig], masz brudne tapy [your paws are dirty], stul pysk! [shut your muzzle - shut your trap!], bodaj byś zdecht! [may you die (about animals)]". [translation mine M.Z] (Kempf 1985; 125). Kempf writes, that such a phenomenon - "special" lexicon for animal body parts and behavior is also characteristic for other Slavic languages, cf. izdochnut', dvolet' (Russian), crći (Serbian) - to die about animals, morda (Russian), tlama (Czech) - a muzzle. He notices that there were not such "worse" words for animals in Hebrew in the Old Testament, and also that such phenomena did not occur in Greek and Latin.

The last group described in the present article comprises derivatives of animal names. This class is also quite extensive and contains mostly lexemes which emphasize human mental or physical features, such as cielęcy [ciele - calf] 'naive, not very smart', cotorrear [cotorra - parrot, magpie] 'to chatter, to prattle 
away'. Such lexemes are also generally offensive and can be used as an insult. As Piotr Wróblewski writes, "One may talk about the derivatives of animal names in the aspect of how people judge their mutual actions, behaviour and efforts, when they want to show them in a very negative light, since these lexemes are most frequently used as elements of depreciative metaphors [...]. Comparing a man with an animal or ascribing animal features to him, is therefore in the common opinion noticeable, rightly or not, as humiliation of the human being" (Wróblewski 2000, 660) [translation mine M.Z].

The described class of lexemes shows that thinking about a human being in terms of an animal is very common and has taken root in both languages. There are some differences, but rather small and not very significant. As Hilary Nesi points out, "[animal metaphors] are common in most, if not all, cultures, and because in many cases they evoke a strong emotional response. The conceptual metaphor 'a human being is an animal' seems to be extremely widespread. Animal metaphors have their roots in traditional, rural society; they are often linked to proverbs and folk stories which, although they have been 'laundered out of educated English speech and writing' (Scollon 1993; 48) continue to feature in both conversation and journalism in many cultures [...]. Animal metaphors can be used for this purpose [a depersonalizing criticism] ('He's a little monkey') but it is also, of course, used to maximize personal impact, both in endearments and, perhaps more frequently, in insults" (Nesi 1995; 273-274).

\section{BIBLIOGRAPHICAL REFERENCES}

Alcover, Antoni M. \& Francesc de Borja Moll. 1930. Diccionari catalàvalencià-balear. Palma de Mallorca: Impremta d'Antoni M. Alcover.

ALLAN Keith \& Kate Burridge. 1991. Euphemism and Dysphemism, Language Used as Shield and Weapon. Oxford-New York: Oxford University Press.

ANUSIEWICZ, J. and J. Skawinski (eds.). 1998. Stownik polszczyzny potocznej. Warsaw: PWN.

Burgen, Stephen. 1996. Your Mother's Tongue. A Book of European Invective. London: Indigo.

CHAmizo Domínguez, Pedro José. 1998. Metáfora y conocimiento. Málaga: Anexos de «Analecta Malacitana», Vol. 16.

CHamizo Domínguez, Pedro José. 2004. «La función social y cognitiva del eufemismo y del disfemismo», en Panace@. Vol. V, Núm. 15, pp. 45-51. 
CHAMizo Domínguez, Pedro José. 2005. La metáfora (semántica y pragmática). Athens [Georgia]: Proyecto Ensayo Hispánico. $<$ http://www.ensayistas.org/critica/retorica/chamizo/>

CHAmizo Domínguez, Pedro José \& Francisco Sánchez Benedito. 2000. Lo que nunca se aprendió en clase: eufemismos y disfemismos en el lenguaje erótico inglés. Granada: Comares. Prólogo de Keith Allan.

CHAmizo Domínguez, Pedro José \& Brigitte Nerlich. 2002. «False friends: their origin and semantics in some selected languages». Journal of Pragmatics. 34, pp. 1833-1849.

CHAmizo Domínguez, Pedro José \& Thomas Fuyin-Li. 2004. «Zoosemy in Spanish and Chinese: A semantic and cognitive analysis». Research in Foreign Language and Literature. 4-1, pp. 78-84.

Corominas, Joan \& José A. Pascual. 1984-87. Diccionario crítico etimológico castellano e hispánico. Madrid: Gredos.

DICCIONARIO DE LA LENGUA ESPAÑOLA. 2005. Madrid: Real Academia Española de la Lengua. < http://www.rae.es/>

ECHEVARRía Isusquiza, Isabel. 2003. «Acerca del vocabulario español de la animalización humana». Círculo. < http://www.ucm.es/info/circulo/no15/echevarri.htm >

FERNÁNDEZ Fontecha, Almudena \& Rosa María Jiménez Catalán. 2002. "Semantic derogation in animal metaphors contrastive-cognitive analysis of two male/female examples in English and Spanish». Journal of Pragmatics. 35, pp. 771-797.

HALUPKA-REš̉ETAR, Sabina \& Biljana Radić. 2003. «Animal names used in addressing people in Serbian». Journal of Pragmatics. 35. pp. 1891-1902.

Holder, Robert W. 2003. A Dictionary of Euphemisms. How Not To Say What You Mean. Oxford: Oxford University Press.

KEMPF, Zdzisław. 1985. Wyrazy $<<$ gorsze $>>$ dotyczace zwierzat, „Język Polski” nr 2-3, 125-144.

KLEPARSKI, Grzegorz A., 2002. «Lusta mint a disznó: A hunt for correlative zoosemy in Hungarian and English». Studia Anglica Resoviensia, 6, pp. 9-32.

LAKOFF, George, \& Mark Johnson. 1980. Metaphors We Live By. Chicago: The University of Chicago Press.

MALISZEWSKI, Bartłomiej. 2003. Stereotypizacja i profilowanie symbolicznych znaczeń wybranych zwierzat w językowo-potocznym obrazie świata, „Poradnik Językowy” 28, 22-35. 
MARTSA, Sándor, 2001. «On the Lexicalisation of Conceptual Metaphors: A Cross-Linguistic Study of Animal-Based Metaphors», in Andor, József, Szucs, Tibor, \& Terts, István (eds.). Szines eszmék nem alszanak... Szépe György 70. születésnapjára. Pécs: Lingua Franca Csoport, pp. 774-798.

MCDONALD, James. 1988. A Dictionary of Obscenity, Taboo and Euphemism. London: Sphere Books.

NESI, Hillary. 1995. A modern bestiary: a contrastive study of the figurative meanings of animal terms, „ELT Journal”, vol. 49/3, 273-278.

OXFORD ENGLISH DICTIONARY. 1989. The Oxford English Dictionary. Ed. by J. A. Simpson and E. S. C. Weiner. Oxford: Clarendon Press.

TOKARSKI, Ryszard. 1991. Wartościowanie cztowieka w metaforach językoreych, „Pamiętnik Literacki” LXXXII, z. 1, 144-157.

WRÓBLEWSKI, Piotr. 2000. Językowy obraz ludzkich zachowań w świetle metaforycznych użyć czasowników zwierzęcych i odzwierzęcych, „Prace Filologiczne” t. 45, 659-680.

\section{Appendix}

1. Names of animals which can be used as insults

\subsection{Animal names referring to physical features of humans}

Both sexes

SPANISH

Cerdo/cerda [pig] pig (dirty person).

Chancho/chancha [sow] filthy man/woman (America).

Escarabajo [beetle] dwarf, stunted person.

Gorgojo [weevil] midget, dwarf, small person.

Gorrino/gorrina [pig] pig.

Grajo [rook, crow] underarm odor (Antilles, Colombia, Ecuador, Peru).

Guarro/guarra [pig] pig, a dirty pig.

Lagarto [lizard] glutton (El Salvador, Nicaragua).

Lechón/lechona [sucking pig] filthy man/woman.

Lirón [dormouse] sleepyhead.

Lobo/loba [wolf] dish, cute woman (Ecuador).

Loro [parrot] a very ugly person.

Marmota [marmot] sleepyhead.

Marrano/marrana [pig] a pig, a dirty pig.

Mastodonte [mastodon] big/fat person.

Mico [monkey] a small and very ugly person.

Pavo [turkey] hump, a humpback (Ecuador). 
Puerco/puerca [pig/sow] pig, a dirty pig.

Rapaz/rapaza [predatory] lad/lass.

Rémora [remora] a hindrance.

Sapo [toad] a small person (El Salvador, Guatemala, Honduras, Mexico).

Verraco/verraca [male pig, boar] pig, a dirty pig (Cuba).

\section{Female}

POLISH

Fladra [flounder] a dirty, sloppy woman (SJPSz), (SPP).

Klępa [female elk] a woman who is languid and shapeless, untidy, sloppy (SJPSz).

Koczkodan [guenon] ugly woman, strangely dressed (SJPSz).

Krowa [cow] a shapeless woman, languid (SJPSz).

Ropucha [toad] an old woman, who is stout, languid, ugly, not attractive (SJPSz).

Wydra [otter] a woman who is provocatively dressed (SJPSz).

SPANISH

Arpia/harpia [harpy] ugly and skinny woman.

Bicha [snake] girl (El Salvador, Honduras).

Cabra [goat] girl (Chile).

Cacatúa [cockatoo] ugly old woman.

Pava [turkey-hen] dull woman.

Penco [hack nag] ugly and extremely thin woman (Cuba).

Polla [young hen] young woman.

Tarasca [mythological monster] terrible woman

Male

POLISH

$B y k$ [bull] big, stout, strong man (SJPSz).

Cap [billy goat] old man (SPP).

Stoń [elephant] an obese, languid man, moving in a clumsy way (SJPSz).

Śrwintuch [male from of świnia - 'pig'] a dirty, sloppy man (SJPSz).

Szczeniak [puppy] a young boy, a child, a whippersnapper (SPP) (SJPSz).

Szczurek a man with thin, narrow, small face; someone small, thin.

Wieprz [hog] big, obese man (SJPSz).

SPANISH

Bicho [bug] boy (El Salvador, Honduras).

Macaco [macaque] ugly and deformed man (Bolivia, Chile, Cuba).

Pollo [chicken] youngster.

Tagarote [sparrow hawk] 1) glutton (Costa Rica); 2) longlegs 


\subsection{Animal names referring to pudenda and sexual activity}

\section{POLISH}

cipka [young hen]/cipa [augmentative form] vagina (SJPSz), (SPPW), (SPP).

dziobak [platypus] penis (SPPW).

fladra [flounder] a whore (SJPsz).

kociak [kitten] chick (SJPSz).

koń [horse] penis (SPPW).

$k o t$ [cat] hair on a woman's pubes (SPP).

mereka [diminutive of mewa - seagull] a whore, in port city (SJPSz).

ptak [bird]/ ptaszek [deminutive form] penis (SPP).

rogacz [stag] a man whose wife is unfaithful, a cuckold (SJPSz).

samica [animal female] (SJPSz).

samiec [animal male] lascivious man (SJPSz).

suka [bitch] lascivious woman (SPPW), (SJPSz).

\section{SPANISH}

Araña [spider] whore.

Bicha [snake] girlfriend (El Salvador).

Cabrón/cabrona [he-goat] 1) cuckold; 2) pimp, procurer (Southern America).

Capón [capon] castrated.

Chivo [kid, baby/young goat] pimp (Nicaragua).

Coneja [doe] woman who gives birth very frequently.

Gallo [cock, rooster] clitoris (El Salvador).

Ganso [gander, goose] queer, pouf (Cuba).

Lagarta [female lizard] whore, tart.

Mariposa [butterfly] queer, pouf.

Mico [monkey] vagina (Costa Rica, El Salvador, Guatemala, Nicaragua).

Mico [monkey] lustful man.

Mula [mule] queer, pouf (Cuba).

Novillo [young bull] cuckold.

Pájaro [bird] 1) queer, pouf (Costa Rica, Cuba); 2) penis (Guatemala, Venezuela).

Paloma [dove] prick, penis (Central America, Venezuela).

Paloma [dove] vulva (Guatemala).

Pato [duck] queer, pouf (Antilles, Nicaragua, Venezuela).

Penco [hack, nag] whore (Canary Islands).

Perra [bitch] whore.

Polla [young hen] prick, penis.

Tigresa [tigress] vamp, femme fatale.

Vampiresa [she-vampire bat] 1) vamp; 2) femme fatale.

Yegua [mare] queer, pouf (Cuba).

Zángana [drone] whore (Nicaragua)

Zorra [vixen] whore. 


\section{Animal names naming features of human character}

Both sexes

POLISH

Owca [sheep] someone with weak will, without her/his own opinion.

Papuga [parrot] copycat.

Ptotka [roach] small fry.

Prosiak/prosię [piglet] slob.

Truteń [drone] sponger.

$W a \dot{z}$ [snake] someone cunning, sly.

Hiena [hyena] ruthless, exploiting suffering people (SJPSz).

Gadzina [derivative from gad - 'reptile'] mean man (SJPSZ).

Świnia [pig] mean, obscene man (SJPSz) (SPP).

SPANISH

Abejorro [bumblebee] bore, nuisance.

Acémila [donkey, ass] animal, ass, brute.

Alacrán [scorpion] scandalmonger, gossip.

Animal [animal] brute, lout, beast.

Araña [spider] resourceful/thrifty person.

Arpia/harpia [harpy] covetous/greedy person.

Arrendajo [jay] mince, ape (imitator).

Asno/asna [ass, donkey, she-ass] ass, fool, dunce, dimwit, twit.

Avispa [wasp] aggressive and irritable person (Cuba).

Basilisco [basilisk] irascible/irritable person.

Bestia [beast] beast, brute, ignoramus, dunce, idiot.

Besugo [sea bream] idiot, drip, twerp.

Bicho [beast, bug] nasty piece of work.

Borrego/borrega [yearling] 1) simpleton, dope; 2) sheeplike/mindless person.

Búbo [owl] recluse, unsociable person.

Buitre [vulture] vulture.

Burro [ass/donkey] 1) coarse, brusque; 2) lout, brute.

Caimán [caiman/alligator] sly old fox.

Calandria [calandra dark] malingerer.

Camaleón [chameleon] chameleon.

Carcoma [woodworm] spendthrift.

Carnero [ram] sheeplike/mindless person (Chile, Cuba, Peru).

Cernicalo [kestrel] lout, brute.

Chicharra [cicada] chatterbox.

Chinche [bedbug] fusspot

Chota [young goat] 1) joker (Cuba); 2) lazy person (Puerto Rico).

Cochino/cocbina [pig/swine] rude man/woman. 
Cordero/cordera [lamb/ewe lamb] lamb.

Cotorra [parrot, magpie] chatterbox, windbag.

Cuco [cuckoo] crafty/cunning person, wily bird.

Culebra [snake] debtor (Colombia, Ecuador).

Erizo [hedgehog] grumpy/surly person, prickly customer.

Esponja [sponge] sponger.

Fiera [wild animal, beast] brute, cruel person.

Gallina [hen] coward, shy person.

Ganso/gansa [gander, goose] 1) slow/idle man/woman; 2) ill-bread man/woman; 3) clumsy oaf; 4) greedy person (Ecuador).

Gato [cat, tomcat] shrewd.

Gavilán [sparrow hawk] hawk (Venezuela).

Gazapo [young rabbit] sly customer.

Golondrina [swallow] rolling stone.

Guarro/guarra [pig] rude man/woman.

Gusano [worm] worm, despicable person.

Halcón [falcon, hawk] hawk.

Hiena [hyena] brute.

Hurón [ferret] 1) prier, snooper, busybody; 2) unsociable/reserved person.

Ladilla [crab louse] 1) troublesome person or thing (Argentina, Cuba, Uruguay, Venezuela); 2) nuisance, bore (Venezuela).

Lagarto [lizard] mean person (Nicaragua).

Langosta [locust, lobster] scourge, plague.

Lapa [limpet] bore.

Lechuza [barn-owl] busybody (Uruguay).

Liebre [hare] 1) shy and coward person; 2) sly person.

Lobo/loba [wolf/she-wolf] shrewd, astute (Peru).

Marrajo [mako shark] malicious person.

Miura [a kind of bull for bullfighting] devil.

Mona [female monkey] copycat, ape.

Mosca [fly] bore, nuisance, pest.

Moscón [blowfly, meat fly] bore, nuisance, pest.

Ostra [oyster] misanthrope.

Pájaro/pájara [bird] sly old fox/sly woman.

Paloma [dove] 1) peaceful and quite person; 2) dove.

Palomo [(cock) pigeon] spreader, propagandist.

Papamoscas [flycatcher] simpleton, fool.

Parásito [parasite] parasite.

Pardillo [linnet] innocent person, simpleton.

Pato [duck] 1) drip, bore, dull person; 2) victim of flouting (Ecuador).

Pava [turkey-hen] bad luck/jinx (Venezuela).

Penco [hack, nag] 1) dope, ass; 2) lazy bones; 3) despicable person (Andalusia, Canary Islands, Cuba, Honduras, Mexico); 4) coward (Cuba). 
Percebe [goose barnacle] idiot, twit.

Perico [parakeet] rolling stone, particularly a woman.

Perro $[\mathrm{dog}]$ despicable person.

Picaflor [hummingbird] frivolous and inconstant person, especially in love relationships.

Piraña [piranha] mean person (Costa Rica, Cuba, Nicaragua).

Puerco/puerca [pig/sow] rude man/woman.

Quebrantabuesos [lammergeyer] bore.

Raposo/raposa [fox/vixen] sly old fox/sly woman.

Ratón [mouse] vanity/conceit (Uruguay).

Sabandija [bug, creepy-Crowley] 1) louse, slob; 2) person fond of filtring (Uruguay).

Sapo [toad] 1) person who bothers lovers (Cuba); 2) sly old fox (Ecuador, Peru).

Tábano [horsefly] bore.

Tagarote [sparrow hawk] selfish (Costa Rica).

Tarasca [mythological monster]: monster.

Tiburón [shark] 1) shark; 2) egoist, self-seeker.

Tigre [tiger] tiger, bloody-thirsty person.

Vampiro [vampire bat] blood-sucker, parasite.

Verraco/verraca [male pig, boar] 1) despicable (Cuba); 2) simpleton (Cuba).

Víbora [viper] 1) ill-intentioned person; 2) viper, spiteful person.

Yegua [mare] idiot, stupid (Central America, Puerto Rico).

Zángano [drone] 1) idler, lazy-bones; 2) clumsy person, bunger.

Female

POLISH

Gęś [goose]/gąska [diminutive form] slow-witted, naive, stupid woman (SJPSz).

Kociak [kitten] young, sexy, coquettish girl (SJPSz).

Koza [goat] young, cheerful girl (SJPSz).

Krowa [cow] stupid woman (SJPSz)

Kura [hen] especially kura domowa [home hen] a woman, who is interested only in house work, who is narrow-minded, a homebody (SJPSz).

Kwoka [broodhen] unbearable, bothersome, grumbling woman (SJPSZ).

Matpa [monkey] malicious woman (SJPSz).

Wydra [otter] cunning, quarrelsome woman (SJPSz).

Żmija [viper]/ żmijka bad, sneaky person (SJPSz).

SPANISH

Arpia/harpía [harpy] depraved woman.

Borrica [she-donkey] stupid woman.

Burra [she-donkey] rude woman.

Lagarta [female lizard] sly woman, sly minx.

Tigres $a$ [she-tiger] furious, angry woman.

Yegua [mare] rude woman (Cuba, Uruguay). 
Male

POLISH

Bydlak [cow, bull, ox, or calf] brutal, evil man (SJPSz).

Matpiszon [derivative of matpa, 'pig'] malicious man (SJPSz).

Menda [louse] mean man (SPPW).

Samiec [male] lecher (SJPSz).

Skunks [skunk] mean man (SPP).

Sukinkot [bitch-cat] mean man (SPPW).

Sukinsyn [son of a bitch] mean man (SPPW) (SJPSz).

Zwierzę [animal] brutal, evil man (SJPSz).

SPANISH

Atún [tuna fish] rude, brute.

Borrico [ass/donkey] ass, dimwit, dunce.

Gallo [cock, rooster] 1) boss; 2) cocky man.

Lagarto [lizard] sly devil, crafty fellow.

Loro [parrot] chatterbox (El Salvador, Peru, Uruguay).

Macho [he-mule] stupid man.

Merluzo [hake] ninny, silly man.

Mono [monkey, ape] 1) ridiculous person; 2) posh young man.

Moscardón [botfly, blowfly] bore, nuisance, pest.

Moscón [blowfly, meat fly] pushy person.

Mosquito [mosquito] man who visits taverns frequently.

Pavo [turkey] dull or unwary man.

Peje [fish] crafty devil.

Pollo [chicken] sly old fox.

Renacuajo [tadpole] shrimp, mischievous boy.

Rocin [hack, nag] rude, brute man.

Rodaballo [turbot] sly old fox.

Tórtolo [male turtle-dove] lovebird.

Zángano [drone] idler, lazy-bones.

Zorro/zorra [fox] sly person.

Animal names referring to groups of people

POLISH

Bydto [cattle] about a group of people (SJPSz).

Szarańcza [locust] about a group of people, especially devastating, destructive (SJPSz).

SPANISH

Ganado [cattle] crowd, people.

Hatajo [small herd/flock] heap, lot, bunch. 
Jauria [pack of hounds] pack.

Marabunta [plague of ants] crowd.

Perrería [pack of dogs] gang.

Tórtolos [male turtledoves] lovebirds, couple of lovers.

\section{Animal names referring to human jobs or occupation}

\section{POLISH}

Fląra [flounder] whore (SJPSZ).

Goryl [gorilla] bodyguard (SJPSz).

Hiena [hyena] especially in the idiom: biena cmentarna a thief, who robs graves (SJPSz). Merwa [diminutive form of mewa - 'seagull'] a whore, in port city (SJPSz).

\section{SPANISH}

Araña [spider] whore.

Bicha [snake] girlfriend (El Salvador).

Camello [camel] drug pusher.

Carnero [ram] blackleg, strikebreaker (Argentina, Paraguay, Uruguay).

Chiva [young goat] informer (Cuba).

Chota [young goat] informer.

Cobaya [guinea pig] guinea pig.

Cuco [cuckoo] card-sharper.

Garduño/garduña [marten] sneak thief, pickpocket.

Garrapata [tick] soldier who takes care of old and sick horses.

Gato/gata [he-cat/she-cat] 1) sneak thief; 2) servant, home helper (El Salvador, Mexico).

Gerifalte [gerfalcon] 1) bigwig, big shot; 2) boss.

Golondrino [young swallow] deserter.

Gorila [gorilla] 1) body guard; 2) cop or military man who attempts against human rights (Argentina, Guatemala, Nicaragua, Uruguay); 3) putschist (Argentina, Cuba, Uruguay, Venezuela); 4) military man (El Salvador).

Lagarta [female lizard] whore, tart.

Lechuzo [owl] commissioner.

Marmota [marmot] maid.

Mula [she-mule] mule, drug pusher (Ecuador, Colombia).

Papagayo [parrot] informer.

Penco [hack, nag] whore (Canary Islands).

Perico [parakeet] apprentice, trainee (Nicaragua).

Perra [bitch] whore.

Piraña [piranha] thief who acts with others (Peru).

Rana [frog] informer (Colombia).

Rata [rat] thief.

Sapo [toad] 1) informer (Colombia, Costa Rica, Venezuela); 2) voyeur, spy (Chile, Peru); 3) cop (Costa Rica). 
Tagarote [sparrow hawk] 1) scribe, clerk, pen-pusher; 2) gentleman sponger.

Topo [mole] mole (spy).

Zángana [drone] whore (Nicaragua).

Zorra [vixen] whore.

Animal names referring to human secretions diseases injuries and intoxications

POLISH

Gil [bullfinch] snot.

Paw [peacock] vomit.

SPANISH

Alacrán [scorpion] injury, wound (El Salvador).

Cangrejo [crab] cancer (Cuba).

Colorin [goldfinch] measles.

Galgo [greyhound] skin disease similar to itch.

Gavilán [sparrow hawk] growing nail (Andalusia, Central America, Cuba, Puerto Rico, Venezuela).

Golondrina [swallow] boil/tumor in the armpit (El Salvador, Honduras).

Golondrino [young swallow] boil/tumor.

Lobo [wolf] drunkenness.

Mono [monkey, ape] cold turkey, withdrawal symptoms.

Mona [she-monkey] drunkenness.

Merluza [hake] drunkenness.

Mosca [fly] smarting, stinging.

Perra [she-dog] drunkenness.

Ratón [mouse] hangover (Venezuela).

Zorra [vixen] drunkenness.

Names of animal body parts, secretions and actions which can be used as insults

\section{POLISH}

Beczeć [to bleat] 1) to sing badly; 2) to blubber (SJPSz).

Bzykać (sie) [to hum] to have sex (with somebody) (SPPW).

Chlać/ żtopać [about animals - to drink] to booze (SJPSz).

Dosiadać [to mount a horse] to make love (SPPW)

Dziób [beak] mouth (SPP)

Gdakać [to cackle] to prattle, to grouch (SJPSz)

Gęgać [to gaggle] 1) to talk thorough a nose, to gibber; 2) to talk mindlessly or boring (SJPSz)

Gnój [manure] shitface (SJPSz)

Gzić się [about some animals - by anxious behavior show sexual drive; to satisfy sexual drive] to make love (SJPSz).

Jajko/jajo [egg] testicle (SJPSz). 
Jezzor [about animal tongue] tongue (SJPSz).

$K t y$ [fangs] teeth (SPP).

Kopyto [hoof] leg (SJPSz).

Krakać/reykrakać [to caw, to croak] to foretell evil, to croak (SJPSz).

Ktoś bije/rabie/trzepie/wali konia [to beat/ wallop/ spank/ strike a horse] to masturbate (SPPW) (SPP).

Ktoś jedzie/ jeździ na koniu [to ride a horse] about a woman - to make love (SPPW).

Kuper [rump] bottom (SJPSz).

Łapa [paw] hand (SPP).

$Ł e b$ [animal head] head (SJPSz).

Morda [muzzle] face (SPPW).

Mruczeć [to purr] to murmur (SJPSz).

Ogon [tail] penis (SPPW).

Ozór [about animal tounge] tongue (SJPSz).

Paszcza [jaws] mouth (SJPSz).

Podziobać [to peck] to make love (SPPW).

Pysk [muzzle] face (SPPW).

Rechotać [to croak] to cackle (SJPSz).

Rozkulbaczyć [to unsaddle a horse] to take one's virginity (SPPW).

Ryczeć [to roar, to bellow, to bray, to moo] to yell, to blubber, to roar with laughter (SJPSz).

$R y j[$ snout] face (SJPSz).

Rżeć [to neigh] to cackle (SJPSz).

Ścierwo [carcass] bastard (SJPSz).

Skomleć [to whine] to whimper (SJPSz).

Świergotać [to twitter] to speak cheerfully, with a squeaky voice (SJPSz).

Szczecina [bristle] stubble (SJPSz).

Szczekać/ obszczekać/ oszczekać [to bark] to backbite, to defame, to vilify someone; to lie, to make up things; odszczekać [to bark back] 1) to answer impolitely, surly; to retort; 2) to withdraw something unfair that was said about someone (SJPSz).

Trykać [about goats - to butt] to make love (SPP).

Ujeżdżać [to break in a horse] to make love (SPPW).

Warczeć [to growl] to speak in a surly, impolite way (SJPSz).

Wyć [to howl] to howl (SJPSz).

Zad [rump] fat bottom (SJPSz).

Zdechnać [about animals - to die] to die (SPPW).

Żreć [about animals - to eat] to gobble (SJPSz).

SPANISH

Berrear [to low (calves)] 1) to cry; 2) to bawl; 3) to declare, to confess.

$B$ far [to snort] to snort with rage.

Cacarear [to cluck] to boast about. 
Capullo [cocoon] 1) prepuce, head (of the penis); 2) novice, beginner. ${ }^{23}$

Carroña [decaying carcass, carrion] trash (people).

Huevo [egg] 1) testicle, ball; 2) ninny (Uruguay).

Ladrar [to bark] 1) to threaten; 2) to accuse, to brand.

Mugir [to low, to moo, to bellow] to bellow, to roar.

Piar [to cheep, to chirp, to peep] 1) to protest, to grouse; 2) to drink wine.

Rumiar [to ruminate] 1) to ruminate, to think over; 2) to grumble, to growl

Derivatives of animal names used as insult

\section{POLISH}

Baran [ram] Baranieć/ zbaranieć to lose one s head (SJPSz).

Cap [billy goat] Capić to smell in disgusting way (SPP).

Chomik [bamster] Chomikować to hoard, to squirrel away (SJPSz).

Cielę [calf] Cielęcy naive, stupid (SJPSz).

Cietrzew [black grouse] Zacietrzewiać się to get angry (SJPSz).

Fladra [flounder] Fladrowaty dirty, sloppy (SJPSz).

Giez [horsefly] Gzić się [about some animals - by anxious behavior show sexual drive; to satisfy sexual drive] to make love (SJPSz).

Indyk [turkey] Indyczyć/ naindyczyć się to be offended at sth, to take offence (SJPSz).

Jaszczurka [lizard] Jaszczurczy mean, evil (SJPSz).

Krokodyl [crocodile] Krokodyli insincere, feigned (SJPSz).

Krowa [cow] Krowi sleepy, drowsy, blank (SJPSz)

Kukutka [cuckoo] Kukutczy: kukutcze jajo about someone distinguished by something negative $(S J P S z)$.

Kura [hen] Kurzy: kurze tapki small wrinkle; kurzy móżdżek, rozum someone stupid, dense; kurza pamięć very short, bad memory (SJPSz).

Lis [fox] Lisi cunning, sly (SJPSz).

Matpa [monkey] Matpowaćl zmatpować to copy, to emulate someone mindlessly (SJPSz).

Mięczak [mollusk] Mięczakowaty weak, with weak will (SJPSz).

Mysz [mouse] Myszkować to ferret (SJPSz).

Osiot [donkey] Ośli: ośli upór mulishness, ośla gtowa, pała dimwit (SJPSz).

Orwca [sheep] Owczy: owczy pęd to follow the herd (SJPSz).

Papuga [parrot] Papugować to parrot (SJPSz).

Pasożyt [parasite] Pasożytować to make a living out of someone else's expenses (SJPSz).

Pies [dog] Pieski miserable, wretched (SJPSz).

$R y b a$ [fish] Rybi cold, without temperament (SJPSz).

Ślimak [snail] Ślimaczyć to move at a snail's pace (SJPSz).

${ }^{23}$ Although not included in the DRAE, capullo is usually used as a derogatory term meaning stupid or ninny. 
Struś [ostrich] Strusi: strusia polityka too careful, cautious politics, strusi żoładek very healthy stomach (SJPSz).

Świna [pig] Świnić (się)/ ośrwinić/ześrwinić się/ śrwintuszyć 1) to dirty, to soil; 2) to play a dirty or rotten trick on somebody; to say dirty words (SJPSz).

Szczeniak [puppy] Szczenięcy young, silly (SJPSz).

Wilk [wolf] Wilczy cruel, bad, sneaky, insidious: wilczy apetyt, wilczy głód very strong hunger, wilcze prawo lawlessness (SJPSz).

Wydra [otter] Wydrowaty provocative, quarrelsome, argumentative (SJPSz).

Żaba [frogg] Żabi: żabie oczy bulging eyes (SJPSz).

Żmija [viper] Żmijowaty bad, sneaky, insidious (SJPSz).

Żótw [tortoise] Żótwi: iść, wlec się, posuwać się żótwim krokiem to go at a snail's pace $(S J P S z)$.

Zwierze [animal] Zezwierzęcieć to become mean like animal, not to behave like a man (SJPSz).

Zwierzę [animal] Zwierzęcy fierce, ferocious (SJPSz).

SPANISH

Alacrán [scorpion] Alacranado/alacranada 1) suffering from any vice or disease; 2) suffering from any venereal disease.

Animal [animal] Animalada stupid/bawdy thing to do or say, piece of nonsense.

Asno/asna [donkey] Asnada/asnería silliness. Desasnar to teach good manners to, to civilize.

Borrego/borrega [yearling lamb] Aborregado/aborregada sheeplike, mindless. Aborregar/aborregarse to follow the crowd, to become sheeplike.

Borrico/borrica [ass/donkey] Borricada nonsense, stupid thing/saying. Borricón/borricote dense, stupid, dim.

Buche [craw/maw] Desembuchar to blurt out.

Buitre [vulture] Buitrear to vomit (Bolivia, Chile, El Salvador, Peru). Burro [donkey] Burrada stupid/foolish remark/act.

Cabra [goat] Cabreo anger, rage. Cabrear, 1) to make angry; 2) to bore/tire (Chile). Cabrito/cabrita 1) bastard, swine, bugger; 2) cuckold; 3) customer of a red light house.

Cerdo/cerda [pig] Cerdada foul/lousy trick. Cerdear to shirk.

Chivo/chiva [kid, baby/young goat] Chivatazo telling, informing, tip-off. Chivato/chivata 1) telltale/informer; 2) insolent and vivacious child (Colombia).

Choto/chota [young goat] Choteo teasing, Chotear 1) to joke (Cuba); 2) to discredit (Mexico); 3) to scoff at/to make fun; 4) to make a fool of oneself (Cuba).

Cocbino/cocbina [pig] Cocbinada/cocbinería 1) filthiness; 2) obscenity, foul thing; 3) dirty trick. Acochinar 1) to kill, to bump off (someone unable to defend him/herself); 2) to frighten; 3) to acquire dirty habits (moral and physical).

Cola [tail] Colear to invite oneself to a meeting or party (Venezuela).

Conejo [rabbit] Conejillo de Indias guinea pig. 
Cotorra [parrot, magpie] Cotorrear to chatter, to prattle away. Cotorreo chatter, prattle, chattering. Cotorrón/cotorrona 1) old person affecting youthfulness/pretending be young; 2) old bachelor/maid.

Cuerno [horn] Cornudo/cornuda cuckold.

Gallo [cock/rooster] Engallado/engallada arrogant, haughty. Engallamiento arrogance. Gallear 1) to brag; 2) to put on airs and graces, to be arrogant; 3) to get furious and swear, Galleo showing off/bragging. Gallito braggart.

Ganso/gansa [gender/goose] Gansear to do/say daft things.

Gansada silly/daft thing.

Gato [cat, tomcat] Gatazo swindle. Gatear to steal/pilfer. Gatera young pickpocket. Gatuperio imbroglio/intrigue/dirty business. Pelagatos poor devil, ragamuffin.

Gorrino/gorrina [pig] Gorrinada 1) dirtiness; 2) dirty trick.

Guarro/guarra [pig] Guarrada 1) dirtiness, filthiness; 2) obscenity; 3) dirty/foul/lousy trick.

Gusano [worm] Gusanera great passion.

Hocico [snout, muzzle] Abocicar 1) to beat in a argument; 2) to surrender in an argument, Hocicar 1) to kiss repeatedly, 2) to fall on one's face; 3) to come across something; 4) to bear/put up with. Hocicón/hocicona, bocicudo/bocicuda thicklipped, bubbler-lipped.

Huevo [egg] Abuevado/abuevada 1) boring, disgusted (Costa Rica, Nicaragua), 2) indolent, lazy (Costa Rica), 3) ashamed (El Salvador, Honduras). Huevear 1) to disturb/bother (Chile); 2) to steal/pilfer (El Salvador, Guatemala, Honduras); 3) to idle (Chile, Mexico). Huevón/buevona 1) idler; 2) idiot/imbecile.

Hurón [ferret] Huronear to pry, to ferret, to swoop.

Jamón [haunch, ham] Jamona 1) old woman, particularly when she is fat; 2) (Puerto Rico) spinster, old maid.

Lagarto [lizard] Lagartón/lagartona sly, wily, crafty devil.

Macho [male, he-mule] Machada stupidity. Machismo male chauvinism. Machista male chauvinistic. Machorra butch woman, virago (Mexico). Machota mannish woman, virago. Marimacho mannish woman, virago.

Marrano/marrana [pig] Marranada 1) dirty/filthy/foul/rotten trick; 2) filthy/mucky/grubby thing.

Mono/mona [monkey, ape] Monada/monería 1) pretended/affected gesture; 2) silliness. Monigote 1) rude and brute person; 2) puppet, person with a weak character.

Mosca [fly] Amoscamiento anger, temper. Mosquear 1) to smell fishy; 2) to beat,

Mosquearse to get annoyed/irritated, Mosqueo resentment, suspicion

Moscón [blowfly, meat fly] Mosconear 1) to annoy/bother/pester; 2) to be pigheaded, Mosconeo pestering.

Pájaro/pájara [bird] Pajarraco/pajarraca rogue, villain.

Pata [animal leg] Patán 1) yokel; 2) lout boor. Pataleta 1, tantrum; 2) quarrel, anger. Patatús faint, fainting. Patidifuso/patidifusa flabbergasted, dumb founded, nonplussed. Patitieso/patitiesa 1) paralyzed; 2) stiff, starchy; 3) stuck up/strait-laced. 
Patochada blunder/bloomer. Patoso/patosa 1) tiresome, wearisome; 2) clumsy, awkward.

Pavo/pava [turkey] Pavisoso/pavisosa silly, stupid, foolish, ninny, nincompoop, fool. Pavitonto/pavitonta ninny, nincompoop, fool, silly, stupid, foolish. Pavoneo strutting, showing off. Pavada dullness. Pavonear/pavonearse 1) to strut; 2) to delude.

Pechuga [breast (of fowl)] Pechugona breasted girl/woman. Pechugón/pechugona shameless/cheeky (Central America, Chile, Colombia, Peru, Venezuela).

Piojo [louse] Piojoso/piojosa 1) stingy, mean; 2) dirty, filthy.

Pluma [feather] Desplumar 1) to fleece, to clean up; 2) (Andalusia) to fart.

Polla [young hen] Gilipollas ninny. Gilipollez bullshit, bloody stupid thing to do.

Pollo [chicken] Empollón/empollona swot, grind.

Pollastre youngster. Pollear to become/get interested in the opposite sex. Pollastro/pollastra youngster.

Puerco/puerca [pig] Porquería 1) dirty trick; 2) rudeness.

Raposo/raposa [fox] Raposería cunning, artfulness, guile.

Zorro/zorra [fox] Zorrería cunning, artfulness, guile.

Pedro J. Chamizo Domínguez

Fecha de recepción: 20/09/2006

pjchd@uma.es

Fecha de aceptación: 20/12/2006

Facultad de Filosofía y Letras

Departamento de Filosofía

Campus de Teatinos

E-29071-MÁLAGA (ESPAÑA)

M. Magdalena Zawislawska

zawisla@uw.edu.pl

ul. WALEWSKA 5 m. 31

04-022 WARSZAWA

POLONIA 